\title{
Adenosine Triphosphatases of Rat Pancreatic Islets
}

\author{
COMPARISON WITH THOSE OF RAT KIDNEY
}

\author{
Seymour R. Levin, Barry G. Kasson, and June F. Driessen, Medical Service and \\ Diabetes Research Laboratory, Wadsworth Veterans Administration Hospital, \\ and Department of Medicine, University of California at Los Angeles, \\ Los Angeles, California 90073
}

\begin{abstract}
A B S T RACT Electrolyte fluxes are fundamental to normal endocrine pancreatic function. Adenosine triphosphatases (ATPases) are enzyme systems believed to modulate electrolyte movements across membranes in a number of cell types. This study was undertaken to measure cation-dependent ATPases of rat pancreatic islets. In addition, we compared effects of substances which influence endocrine pancreatic function upon ATPases in homogenates of islets and kidney, the latter being a tissue which would not be expected to have a stimulus-secretion response to substances which activate islets.
\end{abstract}

Both tissues were generally similar with respect to apparent Michaelis constant (ATP) of $\mathrm{Na}^{+} \mathrm{K}^{+}$ATPase, $\mathrm{Mg}^{++}$ATPase, and $\mathrm{Ca}^{++}$ATPase. In islets and kidney, $\mathrm{Na}^{+} \mathrm{K}^{+}$ATPase specific activity was increased when the Na:K ratio was lowered from 250:1 (175:0.7 $\mathrm{mM})$ to $5: 1(100: 20 \mathrm{mM})$. Inhibition of $\mathrm{Na}^{+} \mathrm{K}^{+} \mathrm{ATPase}$ at either $\mathrm{Na}: \mathrm{K}$ ratio by ouabain, an activator of secretion, and enhancement of the high-ratio $\mathrm{Na}^{+} \mathrm{K}^{+}$ATPase by diphenylhydantoin, an islet secretory inhibitor, were also common to both tissues.

Because both inhibition and enhancement of $\mathrm{Na}^{+}$ $\mathrm{K}^{+}$ATPase could be studied at the high $\mathrm{Na}: \mathrm{K}$ ratio, we examined the effect of regulators of secretion upon the activity of this enzyme. Like ouabain, substances which induce or support islet secretion, glucose $16 \mathrm{mM}$ or $3.3 \mathrm{mM}$, arginine $14.2 \mathrm{mM}$ (with $3.3 \mathrm{mM}$ glucose), or $\mathrm{Ca}^{++} \mathbf{l m M}$, inhibited high-ratio islet $\mathrm{Na}^{+} \mathrm{K}^{+}$ATPase. Like diphenylhydantoin, the inhibitors of insulin secretion, diazoxide $0.22 \mathrm{mM}$, or $\mathrm{NH}_{4} \mathrm{Cl} 16 \mathrm{mM}$, enhanced this islet ATPase. Neither valine, which is nonsecretogenic, nor arginine without glucose, which is a weak secretagogue, had any effect upon islet $\mathrm{Na}^{+} \mathrm{K}^{+}$ATPase. We examined the effect of these substances upon other cation-dependent islet ATPases. $\mathrm{Ca}^{++}$in-

Received for publication 12 May 1977 and in revised form 14 March 1978. hibited $\mathrm{Mg}^{++} \mathrm{ATPase}$, and glucose inhibited $\mathrm{Ca}^{++} \mathrm{ATP}-$ ase. Leucine, $22.9 \mathrm{mM}$, which induces insulin secretion in the absence of glucose, suppressed islet $\mathrm{Ca}^{++}$. ATPase and had no effect upon high-ratio $\mathrm{Na}^{+} \mathrm{K}^{+}$ATPase.

In contrast to the observations in the islets, most substances which influence islet function had no effect on kidney ATPases, or effects which were different from those seen in islets. Except for ouabain, none of these substances influenced the three kidney ATPases in a manner similar to that seen with islets.

These findings support the hypothesis that cationdependent ATPases are involved in specificity of islet response to substances which influence endocrine pancreatic activity.

\section{INTRODUCTION}

There is abundant evidence which supports the concept that enzyme systems modulate cellular electrolyte fluxes (1-4). Sodium-potassium-activated adenosine triphosphatase $\left(\mathrm{Na}^{+} \mathrm{K}^{+} \mathrm{ATPase}\right)^{1}$ is associated with sodium and potassium transport in many tissues (5). This enzyme also requires magnesium ions for its activity, and is, in most preparations, accompanied by a magnesium-dependent adenosine triphosphatase ( $\mathrm{Mg}^{++}$ATPase) (1), which is not dependent upon sodium or potassium ions. A calcium-activated adenosine triphosphatase $\left(\mathrm{Ca}^{++}\right.$ATPase $)$has been described as well (3). This latter system has variable dependency upon magnesium, sodium or potassium ions $(3,6)$.

There have been many investigations regarding purification and physical properties of ATPases (5), and extensive studies of reaction mechanisms, membrane physiology, and drug effects (5) have been reported.

\footnotetext{
${ }^{1}$ Abbreviations used in this paper: $\mathrm{Ca}^{++}$ATPase, calciumactivated adenosine triphosphatase; DPH, diphenylhydantoin; $K_{m}$, Michaelis constant; $\mathbf{M g}^{++} \mathrm{ATPase}$, magnesium-dependent adenosine triphosphatase; $\mathrm{Na}^{+} \mathrm{K}^{+} \mathrm{ATPase}$, sodium-potassiumactivated adenosine triphosphatase.
} 
However, despite the fact that ion movements are essential in cellular function, relatively few studies that relate the ATPases to specialized cell function have been performed (7-11).

The present investigations were undertaken to compare the ATPases of the rat pancreatic islets with those of the more classically studied rat kidney (12). Our data indicate that certain responses of islet ATPases may be associated with cell functions characteristic of the endocrine pancreas and are distinct from those of the kidney.

\section{METHODS}

Normal male albino Sprague-Dawley rats, weighing 300$500 \mathrm{~g}$, were maintained with free access to standard diet and water. Before islet or kidney collection, animals were anesthetized with intraperitoneal pentobarbital sodium, $60 \mathrm{mg} / \mathrm{kg}$.

Islet preparation. For $\mathrm{Na}^{+} \mathrm{K}^{+} \mathrm{ATPase}$ and $\mathrm{Mg}^{++}$ATPase, pancreatic islets of Langerhans were isolated in accordance with the method of Lacy and Kostianovsky (13), collected in $1-2 \mathrm{ml} 0.25 \mathrm{M}$ sucrose and $1 \mathrm{mM}$ Tris-EDTA (Fisher Scientific Co., Fairlawn, N. J.), pH 7.4 , and frozen at $-20^{\circ} \mathrm{C}$. For each experiment, 1,000 islets were used. These were collected over 2-4 days, and stored in $10 \mathrm{ml}$ solution. 1,000 islets/tube for each experiment were similarly isolated and collected for $\mathrm{Ca}^{++} \mathrm{ATPase}$ in $0.3 \mathrm{M}$ sucrose and $10 \mathrm{mM}$ Tris (Fisher Scientific Co., Fairlawn, N. J.), pH 7.4.

Kidney preparation. For $\mathrm{Na}^{+} \mathrm{K}^{+} \mathrm{ATPase}$ and $\mathrm{Mg}^{++}$ATPase, frozen, whole rat kidney was thawed and washed in cold $0.25 \mathrm{M}$ sucrose and $1 \mathrm{mM}$ Tris-EDTA and placed on a cold stage for micro-dissection. The kidney was sliced in longitudinal sagittal section with a scalpel. Dark-red outer renal medulla was obtained by incisions along the boundaries between cortex and light gray inner medulla (14). This region was used because preliminary experiments in our laboratory, and the work of others (14), indicated the highest $\mathrm{Na}^{+} \mathrm{K}^{+}$ATPase activity is found here. Approximately $13 \mathrm{mg}$ (wet weight) of outer renal medulla was obtained for subsequent homogenization. For $\mathrm{Ca}^{++}$ATPase, the kidney was thawed and washed in $0.3 \mathrm{M}$ sucrose and $10 \mathrm{mM}$ Tris $\mathrm{HCl}$. On a cold Petri dish, approximately $13 \mathrm{mg}$ (wet weight) of inner cortex $(14,15)$ was dissected out with a scalpel and forceps, and saved in $2 \mathrm{ml}$ of sucrose-Tris solution for subsequent homogenization. Inner cortex was used for $\mathrm{Ca}^{++} \mathrm{ATPase}$ assay because our preliminary experiments and the work of others (15) showed that this renal region is highest in this enzyme activity.

Homogenization of tissue. For $\mathrm{Na}^{+} \mathrm{K}^{+} \mathrm{ATPase}$ and $\mathrm{Mg}^{++}$ATPase, homogenizing solution was $0.25 \mathrm{M}$ sucrose in $1 \mathrm{mM}$ Tris-EDTA, whereas for $\mathrm{Ca}^{++}$ATPase, a solution of $0.3 \mathrm{M}$ sucrose and $10 \mathrm{mM}$ Tris $\mathrm{HCl}$ was used.

Homogenization was done manually, with the cold solutions described above, in a $2-\mathrm{ml}$ Ten Broeck tissue grinder with a 0.004-0.006-inch clearance (Kontes Glass Co., Vineland, N. J.) with six or seven vigorous passes of the plunger.

Intact islets or kidney slices could be stored for subsequent assay of $\mathrm{Na}^{+} \mathrm{K}^{+}$ATPase or $\mathrm{Mg}^{++}$ATPase, for periods of up to 3 mo without loss of activity. Experiments with these systems were usually performed after $1 \mathrm{mo}$ of storage of intact tissue at $-20^{\circ} \mathrm{C}$. However, after homogenization, enzyme assay was performed within 2-7 days to avoid loss of these qualities. For $\mathrm{Ca}^{++}$ATPase, it was found that intact islets could be stored at $-20^{\circ} \mathrm{C}$ for periods up to $3 \mathrm{wk}$ without loss of activity. Kidney could be stored for up to 3 mo. However, homogenization, centrifugation, and incubation had to take place within a total of 2-5 days to avoid significant loss of activity.

Centrifugation. Homogenates which were subsequently to be assayed for $\mathrm{Na}^{+} \mathrm{K}^{+} \mathrm{ATPase}$ activity were centrifuged at $35,000 \mathrm{~g}$ in $5 \mathrm{ml}$ sucrose-Tris-EDTA for $35 \mathrm{~min}$ in a refrigerated ultracentrifuge (Beckman Instruments, Inc., Spinco Div., Palo Alto, Calif., L5-50) with a SW 50.1 rotor and 5 $\mathrm{cm}^{3}$ cellulose nitrate tubes (Beckman Instruments, Inc., Fullerton, Calif., 305050). Supernates ${ }^{2}$ were discarded and pellets were resuspended in cold $1 \mathrm{mM}$ Tris-EDTA. For islets, $2.6 \mathrm{ml}$ of this solution was used. $0.1 \mathrm{ml}$ of this solution, the vol used for subsequent assay, contained tissue from 40 islets. For kidney, $2.6 \mathrm{ml}$ of suspension was used to achieve $0.5 \mathrm{mg}$ (wet weight) of kidney/ $0.1 \mathrm{ml}$ sample for subsequent enzyme assay. These preparations were rapidly frozen in a test tube on dry ice in acetone and then stored at $-20^{\circ} \mathrm{C}$.

Homogenates which were subsequently to be assayed for $\mathrm{Ca}^{++}$ATPase were initially centrifuged in sucrose-Tris $\mathrm{HCl}$ at $600 \mathrm{~g}$ for $10 \mathrm{~min}$ in a Sorvall RC2-B refrigerated centrifuge (Ivan Sorvall, Inc., Norwalk, Conn.) with a SM 24 rotor. The pellet was resuspended in sucrose-Tris $\mathrm{HCl}$ solution and rehomogenized with three to four vigorous passes of the plunger. Centrifugation of this pellet at $600 \mathrm{~g}$ for $10 \mathrm{~min}$ was carried out. The supernate was discarded. The pellet thus obtained was then suspended in $2.6 \mathrm{ml} 3 \mathrm{mM}$ Tris $\mathrm{HCl}$ and quickfrozen on dry ice-acetone for storage at $-20^{\circ} \mathrm{C}$, to be assayed for enzyme activity within 2-5 days. The final supernate was discarded.

Enzyme assay. Assays for ATPase activity were, from this point, performed identically in islets and kidney and were carried out as follow:

$\mathrm{Na}^{+} \mathrm{K}^{+}$ATPase and $\mathrm{Mg}^{++}$ATPase. Techniques used were modified for adaptation to small amounts of islet tissues. Methods were adapted from work in non-endocrine tissue by Jorgensen and Skou (16) and Lane et al. (17). At $4^{\circ} \mathrm{C}, 0.5$ $\mathrm{ml}$ of incubation solution was added to $0.1 \mathrm{ml}$ of the above tissue homogenate suspension. This incubation solution consisted of (final concentration): $0.5 \mathrm{mM}$ EDTA, $21 \mathrm{mM}$ glycylglycine (Sigma Chemical Co., St. Louis, Mo.), $21 \mathrm{mM}$ L-histidine (Sigma Chemical Co.), and $3.6 \mathrm{mM} \mathrm{MgCl}$. The solution was prepared with or without $\mathrm{NaCl}$ and $\mathrm{KCl}$ in the concentrations and ratios indicated in Results. $10 \mu \mathrm{l}$ of test substance (see below) or of $3 \mathrm{mM}$ Tris buffer was then added. Duplicate samples were vortexed and preincubated at $37^{\circ} \mathrm{C}$ (pH 7.4) for 10 min. Next, $50 \mu \mathrm{l}$ Tris-ATP (Sigma Chemical Co.) (final concentration $3 \mathrm{mM}$ ) was added to all tubes. Samples were incubated in the shaker bath for $10 \mathrm{~min}$ at $37^{\circ} \mathrm{C}$. All incubation tubes were then placed in an ice bath and the reaction was stopped with $50 \mu$ lice-cold $50 \%$ TCA. Correction for spontaneous hydrolysis (nonenzymatic) of ATP was made with tubes which did not contain tissue. Samples were then centrifuged at $1,100 \mathrm{~g}$ for $10 \mathrm{~min}$ and supernates were assayed for inorganic phosphate as described below, with the method of Fiske and Subbarow (18). $\mathrm{Na}^{+} \mathrm{K}^{+}$ATPase activity was defined as the difference between the inorganic phosphate liberated in the presence, and in the absence, of sodium and potassium. $\mathrm{Mg}^{++} \mathrm{ATPase}$ activity was defined as the inorganic phosphate liberated from incubates which contained $\mathbf{M g}^{++}$, but which did not contain sodium and potassium, minus that because of spontaneous (nonenzymatic) breakdown of ATP. This latter activity was found to be equal to that seen when hydrolysis of ATP from solutions which contained $\mathrm{Mg}^{++}$and

${ }^{2}$ The cation-dependent ATPase activities which we measured were not found in these supernates nor were they measurable in $100,000 \mathrm{~g}$ pellets of these supernates. 
tissue was compared to that from solutions which contained tissue but without $\mathrm{Mg}^{++}$.

$\mathrm{Ca}^{++}$ATPase was assayed as follows, from the method of Nakamaru et al. (6). At $4^{\circ} \mathrm{C}$, incubation tubes were prepared so as to contain, at final concentrations: Tris $\mathrm{HCl} 50 \mathrm{mM}$, $\mathrm{CaCl}_{2} 1 \mathrm{mM}$, and ouabain $0.1 \mathrm{mM}$. The test drugs or substances to be described below, when added, were mixed and pipetted into this solution. $0.1 \mathrm{ml}$ of tissue suspension was then added. Tubes were vortexed and placed in a shaker bath at $37^{\circ} \mathrm{C}\left(\mathrm{pH} \mathrm{7.4)}\right.$. As with $\mathrm{Na}^{+} \mathrm{K}^{+} \mathrm{ATPase}$ and $\mathrm{Mg}^{++}$ ATPase assays, appropriate controls for spontaneous ATP degradation were prepared. This was usually $10-25 \%$ of the total inorganic phosphate liberated. After a 10-min preincubation period at $37^{\circ} \mathrm{C}, 50 \mu \mathrm{l}$ of Tris-ATP (final concentration $3 \mathrm{mM}$ ) was added. Incubation of tubes, in duplicate, was continued for $\mathbf{4 5} \mathrm{min}$, and then the reaction was terminated by immersion of the tubes in ice water and quickly adding $50 \mu \mathrm{l}$ of iced $50 \%$ TCA to each tube. $\mathrm{Ca}^{++}$ATPase was defined as the difference between the inorganic phosphate liberated from ATP in the presence of calcium with and without tissue. This was found to be equal to the hydrolytic activity of tissue in the presence or absence of calcium.

Phosphate was measured by the method of Fiske and Subbarow (18), the OD was read at 660 with flow-through microcuvettes in a Gilford spectrophotometer (Gilford Instrument Laboratories, Inc., Oberlin, Ohio). None of the added drugs or substances described below altered characteristics of the phosphate assay standard curve. In both islets and kidney, in the ranges of activity to be described for the three ATPase systems, intraassay coefficient of variation was $12 \%$ or less.

Protein content of tissue suspensions was determined by the method of Lowry et al. (19). The ATPase activity is expressed as micromoles inorganic phosphate released per milligram of protein per hour. Mean islet protein/incubation tube was 13.5 $\pm 0.65 \mathrm{SE} / \mu \mathrm{g}$ for $\mathrm{Na}^{+} \mathrm{K}^{+} \mathrm{ATP}$ ase and $\mathrm{Mg}^{++} \mathrm{ATPase}$ and 8.6 \pm 1.0 $\mu \mathrm{g}$ for $\mathrm{Ca}^{++} \mathrm{ATPase}$. Kidney protein/incubation tube was 29.0 $\pm 0.7 \mu \mathrm{g}$ for $\mathrm{Na}^{+} \mathrm{K}^{+} \mathrm{ATPase}$ and $\mathrm{Mg}^{++}$ATPase and $15.1 \pm 3 \mu \mathrm{g}$ for $\mathrm{Ca}^{++}$ATPase.

Additives. Various drugs and substances with known effects on endocrine pancreatic function were added to both tissues to observe their effects upon ATPase activity. Ouabain octahydrate, L-arginine $\mathrm{HCl}$, sucrose, and L-leucine were purchased from Sigma Chemical Co. Diphenylhydantoin was kindly furnished by Parke-Davis \& Co., Detroit, Mich. Calcium chloride, D-glucose, and ammonium chloride were purchased from Mallinckrodt, Inc., St. Louis, Mo. L-valine was purchased from Mann Laboratories, New York. Diazoxide was kindly furnished by Schering Corp., Kenilworth, N. J.

The effects of incubations in which these drugs or substances were present were compared with activity from control incubations with the paired $t$ test for statistical analysis. A variety of different additives were tested in each experiment. This was done to assure that effects of tested substances could be compared with a corresponding control on several different days.

\section{RESULTS}

\section{Kinetic studies (Fig. 1)}

To compare the characteristics of the enzymes in islets and kidney, apparent Michaelis constant $\left(K_{m}\right)$ (ATP) values were measured in these tissues. In addition, because $\mathrm{Na}^{+} \mathrm{K}^{+}$ATPase activity may vary at different $\mathrm{Na}^{+}$to $\mathrm{K}^{+}$ratios (20), this enzyme was studied at high (250:1) and low (5:1) Na:K ratios. Actual con-
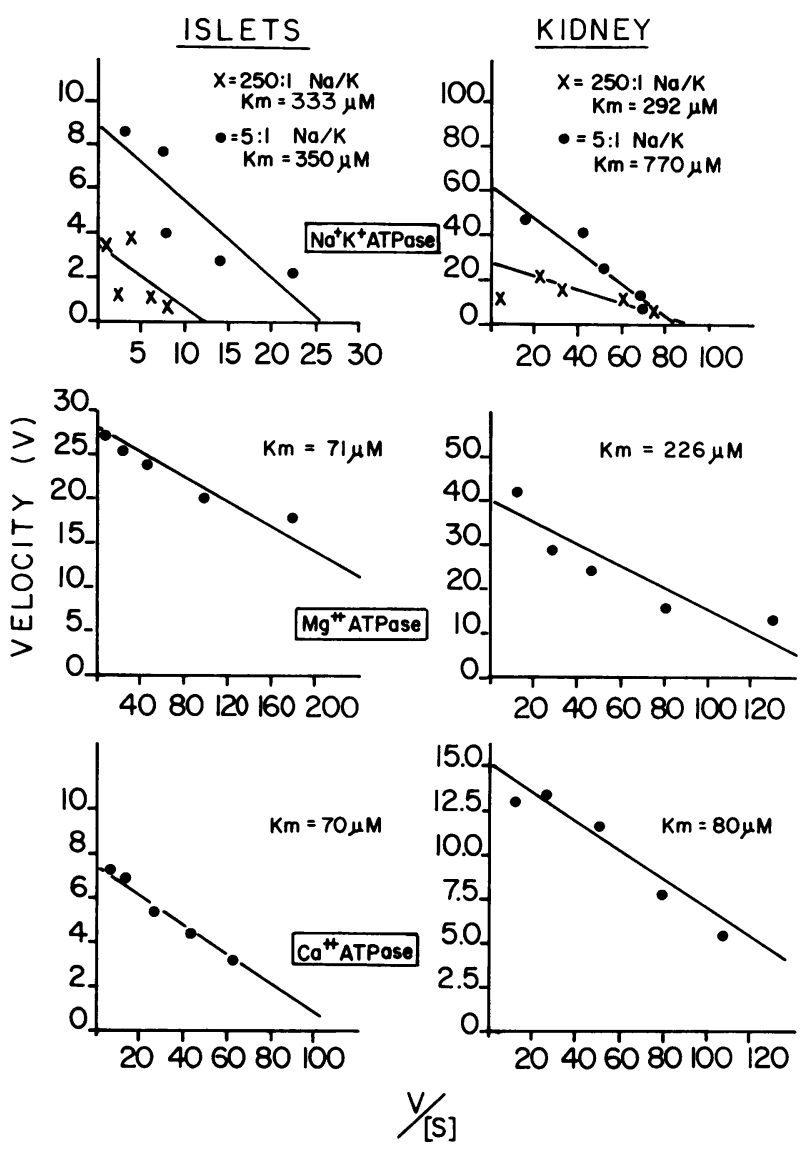

FIGURE 1 Eadie-Hofstee plots representing apparent $K_{m}$ (ATP) for ATPases of islets and kidney. Note that the scaling of the ordinates and abscissae is different on several of the graphs. Each point represents the mean of three paired incubations. $\mathrm{V}=$ micromoles inorganic phosphate/mg protein per hour. $\mathbf{S}=$ substrate concentration (millimolar).

centrations of sodium and potassium were, respectively, at the high ratio, 175 and $0.7 \mathrm{mM}$, and at the low ratio, 100 and $20 \mathrm{mM}$. $\mathrm{Mg}^{++}$was kept constant $(3.6 \mathrm{mM})$.

Eadie-Hofstee plots (Fig. 1) demonstrated, for $\mathrm{Na}^{+} \mathrm{K}^{+}$ATPase, similar affinity for ATP with islets at the high $\mathrm{Na}$ :K ratio compared to outer renal medulla. However, a lowering of the $\mathrm{Na}: \mathrm{K}$ ratio did not alter $K_{m}$ in islets, though this raised $K_{m}$ in kidney. For $\mathrm{Mg}^{++}$ ATPase, $K_{m}$ in islets was one-third that of kidney. $K_{m}$ for $\mathrm{Ca}^{++}$ATPase was similar in both islets and renal tissue.

Specific activity. Table I describes mean control activity in the overall experiment, in which a total of more than 90,000 islets were utilized. $\mathrm{Na}^{+} \mathrm{K}^{+}$ATPase activity comprised a greater proportion of the total activity in kidney than in islets. At the 250:1 Na:K ratio, the mean percent of total $\mathrm{Na}^{+} \mathrm{K}^{+} \mathrm{Mg}^{++}$ATPase activity $( \pm \mathrm{SE})$ which was $\mathrm{Na}^{+} \mathrm{K}^{+}$activated was $9.7 \pm 1.0$ in islets and $18.5 \pm 1.6 \%$ in kidney $(P<0.001)$; whereas, 
TABLE I

ATPase Specific Activity

\begin{tabular}{|c|c|c|}
\hline ATPase & Islet & Kidney \\
\hline & \multicolumn{2}{|c|}{ 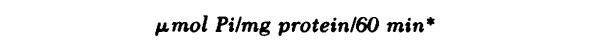 } \\
\hline $\mathrm{Na}+\mathrm{K}+\hbar$ & $2.76 \pm 0.3(n=34)$ & $6.24 \pm 0.5(n=19)$ \\
\hline $\mathrm{Na}+\mathrm{K}+\S$ & $10.9 \pm 2.5(n=8)$ & $40.3 \pm 4.4(n=9)$ \\
\hline $\mathbf{M g}++$ & $25.3 \pm 1.49(n=42)$ & $28.0 \pm 1.25(n=28)$ \\
\hline $\mathrm{Ca}++$ & $8.3 \pm 0.59(n=13)$ & $7.7 \pm 0.54(n=16)$ \\
\hline
\end{tabular}

* Values given are mean $\pm \mathrm{SE}$.

\ With a 250:1 Na:K ratio.

\$ith a 5:1 Na:K ratio.

at the 5:1 ratio, percent of total ATPase which was $\mathrm{Na}^{+} \mathrm{K}^{+}$dependent was $24 \pm 4$ in islets and $57 \pm 3 \%$ in kidney $(P<0.001)$. Moreover, a lowering of the Na:K ratio raised the percent of total ATPase which was $\mathrm{Na}^{+} \mathrm{K}^{+}$-dependent in islets and in kidney $(P<0.001$ in both tissues). It can be seen that specific activity for $\mathrm{Na}^{+} \mathrm{K}^{+}$ATPase was less in islets than in kidney at comparable $\mathrm{Na}: \mathrm{K}$ ratios $(P<0.001)$. Control specific activity, determined from ATP hydrolyzed in the presence of $\mathrm{Na}^{+}, \mathrm{K}^{+}$, and $\mathrm{Mg}^{++}$, vs. hydrolysis in the absence of $\mathrm{Na}^{+}$and $\mathrm{K}^{+}$, but with $\mathrm{Mg}^{++}(20)$, was compared with two other definitions of enzyme activity: (a) ATP hydrolyzed in the presence of $\mathrm{Na}^{+}, \mathrm{K}^{+}$, and $\mathrm{Mg}^{++}$with and without ouabain (16), (b) Hydrolysis of ATP in the presence of $\mathrm{Na}^{+}, \mathrm{K}^{+}$, and $\mathrm{Mg}^{++}$, vs. that seen in the absence of $\mathrm{Na}^{+}$and $\mathrm{K}^{+}$, but with $\mathrm{Mg}^{++}$and ouabain present (21). In 22 experiments with high-ratio $\mathrm{Na}^{+} \mathrm{K}^{+} \mathrm{ATPase}$ in islets, where the three definitions of control activity were compared, no statistical difference was found. This was also true for renal tissue.

Specific activities for $\mathrm{Mg}^{++} \mathrm{ATPase}$ and $\mathrm{Ca}^{++} \mathrm{ATPase}$ were quite similar in both tissues (Table I).

\section{Effects of drugs and substances with known effects upon the pancreatic islets}

Ouabain and diphenylhydantoin (DPH) (Fig. 2). Because enhancement of $\mathrm{Na}^{+} \mathrm{K}^{+}$ATPase is considered to be associated with the pharmacologic effect of DPH (22) and because, in synaptosomes, Festoff and Appel could demonstrate enhancement by DPH only at high $\mathrm{Na}: \mathrm{K}$ ratios (22), we studied effects of ouabain and DPH at both the 5:1 and the 250:1 Na:K ratio. Fig. 2 demonstrates that ouabain, which induces insulin and glucagon secretion (23-27), significantly inhibited $\mathrm{Na}^{+} \mathrm{K}^{+} \mathrm{ATPase}$ in both tissues at both $\mathrm{Na}: \mathrm{K}$ ratios. On the other hand, at the high $\mathrm{Na}: \mathrm{K}$ ratio, $\mathrm{DPH}$, an inhibitor of endocrine pancreatic function (28-36), enhanced this enzyme about $100 \%$ in islets and kidney. This enhancement was not noted at the low $\mathrm{Na}: \mathrm{K}$ ratio. Neither of these drugs influenced $\mathrm{Mg}^{++} \mathrm{ATPase}$ in either tissue.

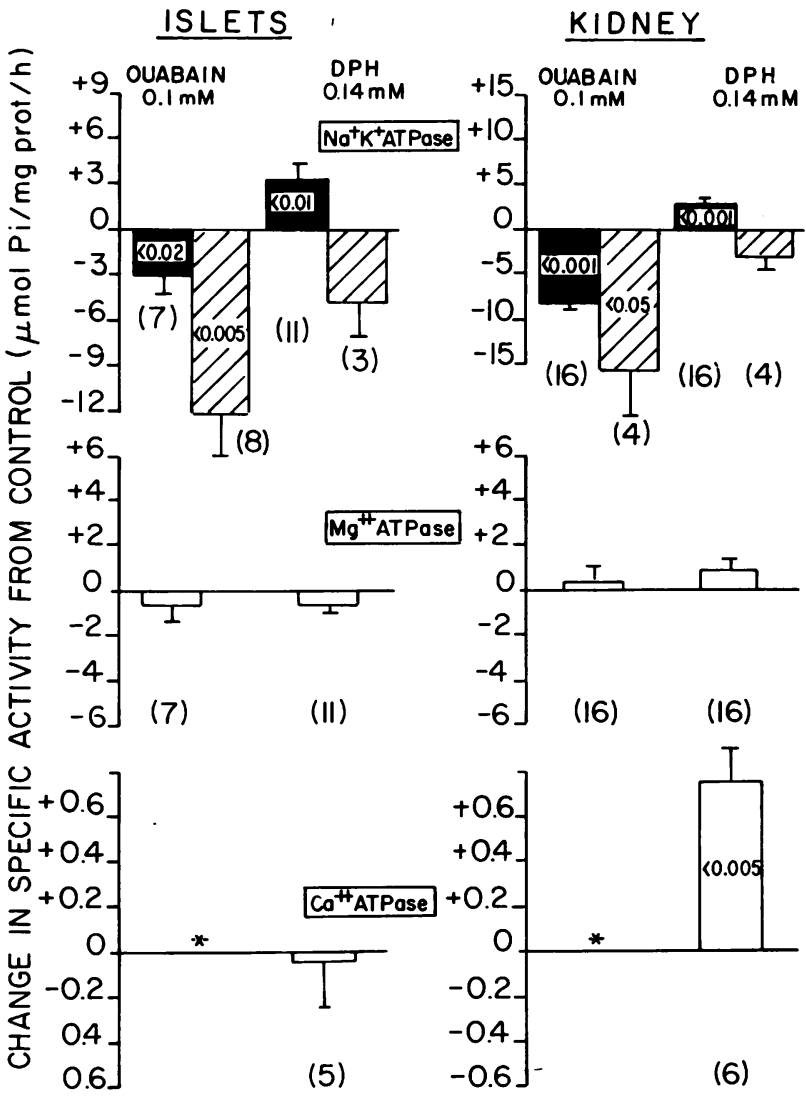

FIgURE 2 Effect of ouabain and DPH upon ATPases of islets and kidney. Changes from control are shown as mean \pm SEM $\mathrm{Na}^{+} \mathrm{K}^{+}$ATPase was examined in the presence of high $\mathrm{Na}: \mathrm{K}$ (250:1) ratios (black columns) or of low (5:1) Na:K ratios (striped columns). Actual cation concentrations were 175:0.7 and 100:20 mM, respectively. $P$ values indicating statistical significance are noted in response columns. Asterisk denotes that ouabain $0.1 \mathrm{mM}$ was added to all $\mathrm{Ca}^{++} \mathrm{ATPase}$ incubations $(3,6)$ so that influence of this drug on $\mathrm{Ca}^{++} \mathrm{ATPase}$ could not be evaluated. Numbers in parentheses indicate the number of paired incubations.

Because ouabain was added to all tubes in the $\mathrm{Ca}^{++}$ ATPase assay, to suppress any residual $\mathrm{Na}^{+} \mathrm{K}^{+}$dependent ATPase activity (3), its effects on $\mathrm{Ca}^{++} \mathrm{ATPase}$ were not measured. DPH significantly enhanced renal $\mathrm{Ca}^{++} \mathrm{ATPase}$, but did not influence this system in islets.

Because, with ouabain and DPH, both inhibition and enhancement relationships could be observed at the high $\mathrm{Na}: \mathrm{K}$ ratio, the $250: 1 \mathrm{Na}: \mathrm{K}$ solution $\left(175 \mathrm{mM} \mathrm{Na}^{+}\right.$, $0.7 \mathrm{mM} \mathrm{K}^{+}$) was chosen for evaluating the effects of all subsequently tested substances.

Effects of glucose and calcium (Fig. 3). In islets, glucose $(16.7 \mathrm{mM})$ inhibited $100 \%$ of $\mathrm{Na}^{+} \mathrm{K}^{+}$ATPase activity as compared with the corresponding control experiments in which sp act was $3.83 \pm 0.9 \mathrm{SE}$. Glucose, $3.3 \mathrm{mM}$, partially inhibited this enzyme $(28 \%)$ in islets. The difference between the inhibitory effects of 


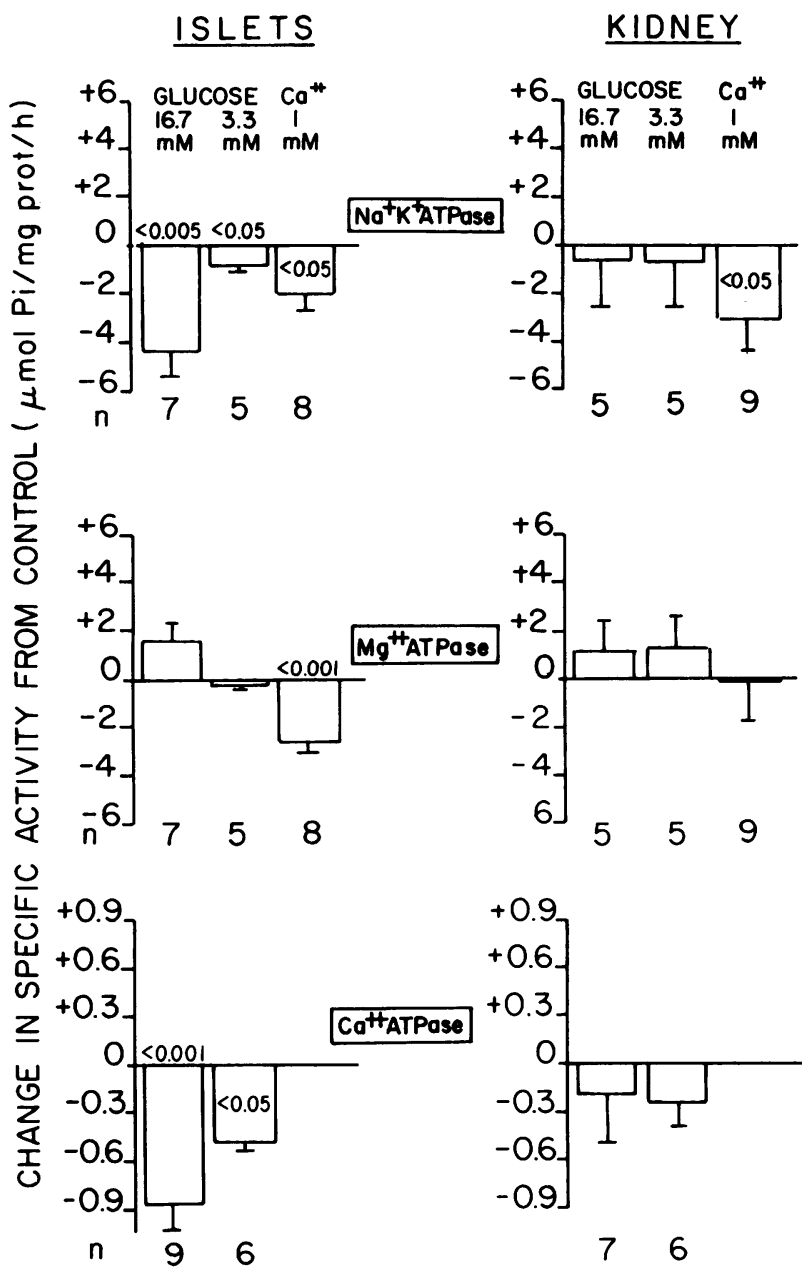

FIGURE 3 Effects of glucose and calcium upon ATPases. Changes from control are shown as mean \pm SEM. $P$ values indicating statistical significance are noted in response columns. $n$ indicates number of paired incubations.

the higher and lower glucose concentrations $(4.4 \pm 0.9$ vs. $0.83 \pm 0.24 \mu \mathrm{mol} \mathrm{Pi} / \mathrm{mg}$ protein per h) was statistically significant $(P<0.02)$. Thus, in islets, high glucose concentrations inhibited $\mathrm{Na}^{+} \mathrm{K}^{+}$ATPase to a degree similar to that produced by ouabain. Glucose did not influence islet $\mathrm{Mg}^{++} \mathrm{ATPase}$, but at both 16.7 and 3.3 $\mathrm{mM}$ suppressed $\mathrm{Ca}^{++} \mathrm{ATPase}$. The degree of inhibition of $\mathrm{Ca}^{++}$ATPase was not significantly greater with the high glucose concentration than it was with the lower, though trends toward a difference were seen (inhibition of $0.87 \pm 0.16 \mu \mathrm{mol} \mathrm{Pi} / \mathrm{mg}$ protein per $\mathrm{h}$ with $16.7 \mathrm{mM}$ glucose vs. $0.48 \pm 0.17$ with $3.3 \mathrm{mM}$ glucose). Despite prominent effects on $\mathrm{Na}^{+} \mathrm{K}^{+}$ATPase and $\mathrm{Ca}^{++}$ATPase in islets, glucose had no effect on the ATPase systems in kidney. Calcium, a modulator of hormone release (37-40), inhibited both islet $\mathrm{Na}^{+} \mathrm{K}^{+}$ATPase $(100 \%)$ and $\mathrm{Mg}^{++}$ATPase (12\%). Calcium reduced renal $\mathrm{Na}^{+} \mathrm{K}^{+}-$
ATPase $51 \%$, while having no effect upon $\mathrm{Mg}^{++}$ATPase in this tissue.

Amino acids (Fig. 4). Arginine $14.2 \mathrm{mM}$, with a background glucose of $3.3 \mathrm{mM}$ which results in biphasic insulin release (41), was associated with suppression of islet $\mathrm{Na}^{+} \mathrm{K}^{+}$ATPase without affecting $\mathrm{Mg}^{++}$ATPase or $\mathrm{Ca}^{++}$ATPase. However, when glucose was omitted from the arginine-islet homogenate incubation tubes at a concentration which is known to give weak, monophasic insulin secretion (41), there was no influence on any of the islet ATPase activities.

In kidney, arginine suppressed $\mathrm{Na}^{+} \mathrm{K}^{+} \mathrm{ATPase}$ with or without $3.3 \mathrm{mM}$ background glucose, and enhanced $\mathrm{Mg}^{++} \mathrm{ATPase}$ only when glucose was present. This amino acid had no effects on $\mathrm{Ca}^{++} \mathrm{ATPase}$ in islets with or without $3.3 \mathrm{mM}$ glucose. On the other hand, renal $\mathrm{Ca}^{++}$ATPase was enhanced by arginine in the absence of glucose. Leucine, which can produce insulin release in the absence of glucose (42), suppressed islet $\mathrm{Ca}^{++}$. ATPase without significantly influencing the other two ATPases. In contrast, leucine enhanced renal $\mathrm{Ca}^{++}$ ATPase and had no effect upon $\mathrm{Na}^{+} \mathrm{K}^{+}$dependent systems.

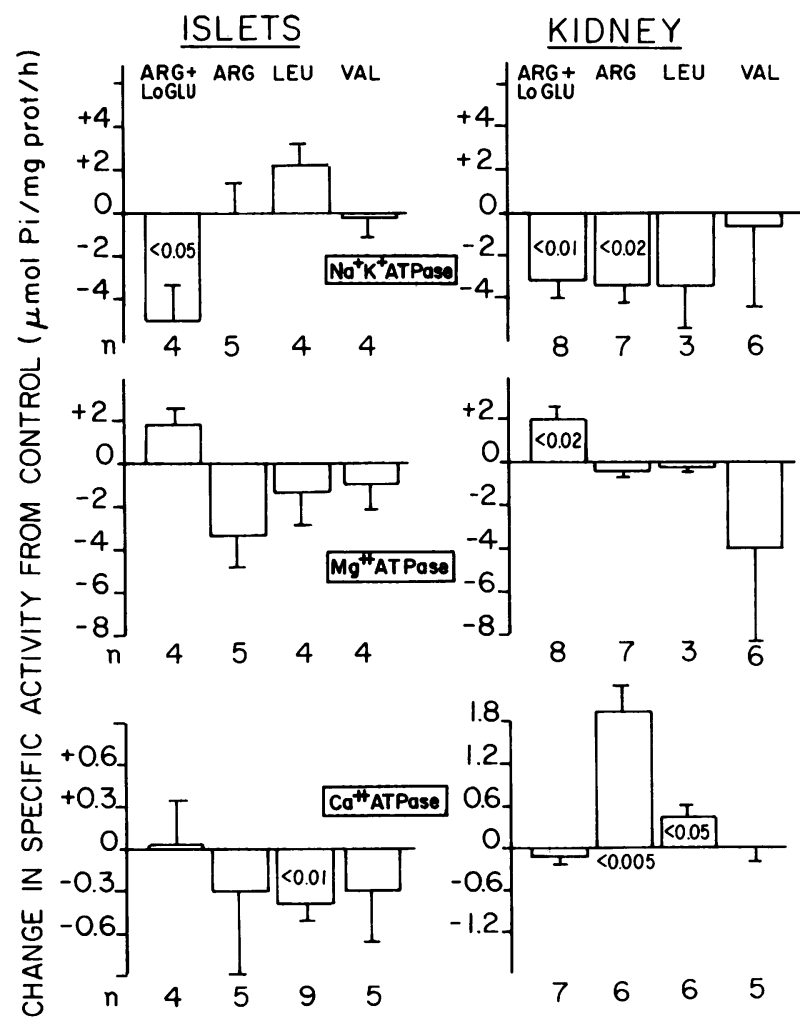

Figure 4 Effects of amino acids on ATPase. Changes from control are shown as mean \pm SEM. $P$ values indicating statistical significance are noted in response columns. $n$ indicates number of paired incubations. Arg = Arginine hydrochloride, $14.2 \mathrm{mM}$, Lo Glu = Glucose, $3.3 \mathrm{mM}$, Leuc = leucine 22.9 $\mathrm{mM}, \mathrm{Val}=$ Valine, $14.2 \mathrm{mM}$. 


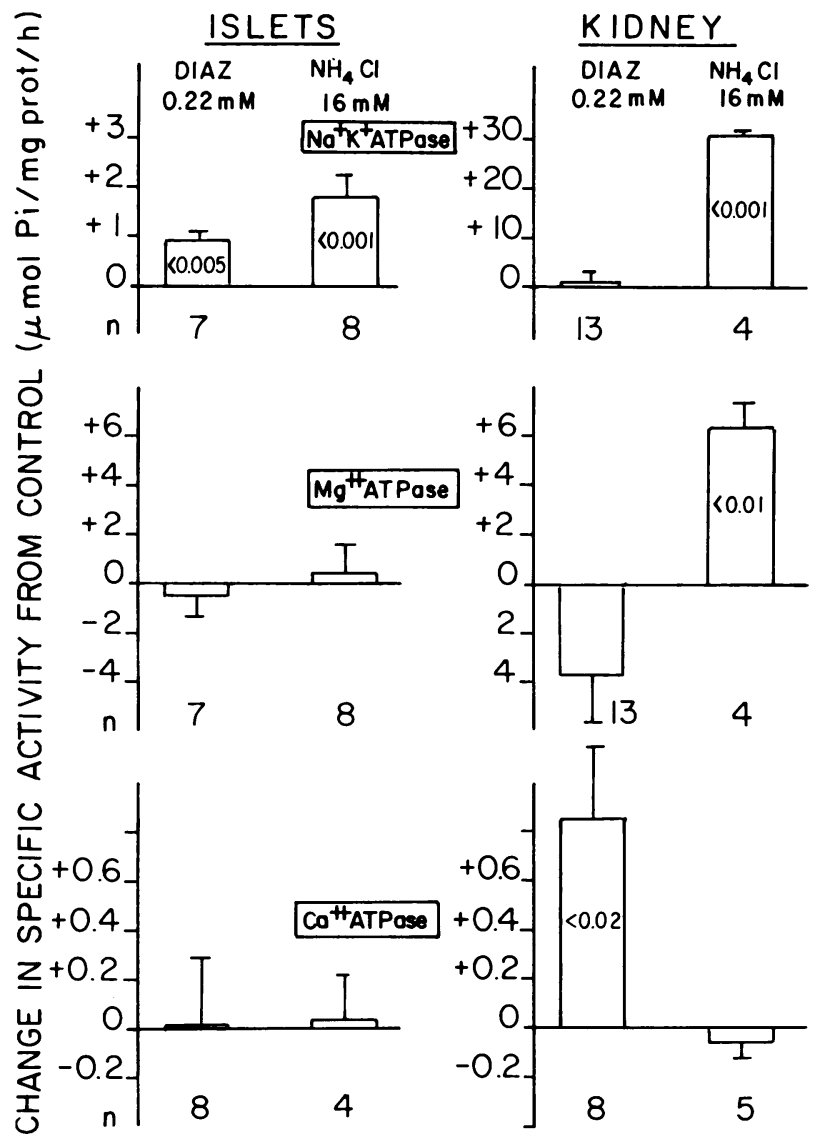

FIGURE 5 Effects of diazoxide and $\mathrm{NH}_{4} \mathrm{Cl}$ upon ATPases of islets and kidney. Changes from control are expressed as mean \pm SEM. $P$ values indicating statistical significance are placed in response columns. $n$ indicates number of paired incubations.
Valine, which does not affect islet secretion appreciably (43), did not alter these ATPases in islets or kidney.

Diazoxide and ammonium chloride (Fig. 5). In addition to DPH, these inhibitors of islet secretion (34, $36,44)$ were studied to contrast with the effects of stimulatory agents. Both diazoxide and $\mathrm{NH}_{4} \mathrm{Cl}$ enhanced islet $\mathrm{Na}^{+} \mathrm{K}^{+}$ATPase $(42 \%$ and $100 \%$, respectively), and did not influence $\mathrm{Mg}^{++}$or $\mathrm{Ca}^{++} \mathrm{ATPase}$. In kidney, responses to these agents were quite different. Diazoxide had no effect on $\mathrm{Na}^{+} \mathrm{K}^{+}$ATPase but significantly enhanced renal $\mathrm{Ca}^{++} \mathrm{ATPase}$. On the other hand, $\mathrm{NH}_{4} \mathrm{Cl}$ enhanced both renal $\mathrm{Na}^{+} \mathrm{K}^{+} \mathrm{ATPase}$ and $\mathrm{Mg}^{++}$ATPase without affecting $\mathrm{Ca}^{++}$ATPase.

Table II summarizes the effect of active substances upon islet $\mathrm{Na}^{+} \mathrm{K}^{+}$ATPase. Suppression or enhancement of enzyme activity by these substances was statistically equal to $100 \%$ of the activity of paired controls. Exceptions were glucose $3.3 \mathrm{mM}$ and diazoxide, which produced alterations that were statistically less than total (28\% mean inhibition and $42 \%$ mean enhancement, respectively).

\section{DISCUSSION}

Previous studies of pancreatic islet function have demonstrated changes in transmembrane potential with secretagogues (45). Requisites for sodium (23), potassium $(23,46,47)$ and calcium $(37-39,47)$ in normal endocrine pancreatic function have also been established. In these present investigations, we have measured the enzymes which are believed to modulate cationic fluxes in a variety of cell types $(1,3,5,11,15)$. The energy for this modulation is thought to be derived from the hydrolysis of ATP.

TABLE II

Substances Which Significantly Influence High-Ratio Islet $\mathrm{Na}+\mathrm{K}+\mathrm{ATPase}$

\begin{tabular}{|c|c|c|c|c|}
\hline & \multirow[b]{2}{*}{ Substance } & \multirow[b]{2}{*}{$(n)^{*}$} & \multicolumn{2}{|c|}{ Activity } \\
\hline & & & Control $t$ & $\begin{array}{l}\text { Change } \\
\text { induced }\end{array}$ \\
\hline & & & \multicolumn{2}{|c|}{$\mu \mathrm{mol}$ Pi/mg protein $/ 60 \mathrm{~min}$} \\
\hline \multirow[t]{6}{*}{$\begin{array}{l}\text { Enhancers of } \\
\text { insulin release }\end{array}$} & Ouabain $0.1 \mathrm{mM}$ & (7) & $3.09 \pm 0.9$ & $3.15 \pm 0.9 \downarrow$ \\
\hline & Glucose $16.7 \mathrm{mM}$ & (7) & $3.83 \pm 0.9$ & $4.42 \pm 0.2 \downarrow$ \\
\hline & Glucose $3.3 \mathrm{mM}$ & (5) & $2.92 \pm 0.5$ & $0.83 \pm 0.2 \downarrow$ \\
\hline & Calcium $1.0 \mathrm{mM}$ & (8) & $3.07 \pm 0.88$ & $1.95 \pm 0.7 \downarrow$ \\
\hline & Arginine $14.2 \mathrm{mM}$ & & & \\
\hline & + Glucose $3.3 \mathrm{mM}$ & (4) & $3.27 \pm 1.13$ & $5.11 \pm 1.5 \downarrow$ \\
\hline \multirow[t]{3}{*}{$\begin{array}{l}\text { Inhibitors of } \\
\text { insulin release }\end{array}$} & DPH $0.14 \mathrm{mM}$ & $(11)$ & $2.65 \pm 0.60$ & $3.50 \pm 1.0 \uparrow$ \\
\hline & Diazoxide $0.22 \mathrm{mM}$ & (7) & $2.09 \pm 0.56$ & $0.86 \pm 0.2 \uparrow$ \\
\hline & $\mathrm{NH}_{4} \mathrm{Cl} 16 \mathrm{mM}$ & (8) & $1.56 \pm 0.13$ & $1.82 \pm 0.4 \uparrow$ \\
\hline
\end{tabular}

* Number of paired incubations.

$\$$ Paired controls which were run with each substance. 
The concept that $\mathrm{Na}^{+} \mathrm{K}^{+} \mathrm{ATPase}$ is related to fundamental fluxes of these ions in islet function has had indirect support through studies of endocrine pancreatic secretion. For example, ouabain, the classic suppressor of $\mathrm{Na}^{+} \mathrm{K}^{+}$ATPase (1), enhances insulin and glucagon secretion (23-27), on the other hand, DPH, an enhancer of $\mathrm{Na}^{+} \mathrm{K}^{+} \mathrm{ATPase}$ activity (22), suppresses insulin and glucagon secretion (28-36). Ouabain increases entry of sodium into cells (48), while DPH increases the outward flux of sodium $(30,49)$. These cation movements are very likely the result of the influence of these drugs upon pumping action of $\mathrm{Na}^{+} \mathrm{K}^{+}$ATPase $(1,11)$. These present studies demonstrate that in islets, as in other tissues, ouabain suppresses $\mathrm{Na}^{+} \mathrm{K}^{+} \mathrm{ATP}$ ase and that $\mathrm{DPH}$, at a high $\mathrm{Na}: \mathrm{K}$ ratio, enhances this enzyme system.

The $\mathrm{Na}^{+} \mathrm{K}^{+}$ATPase system of kidney has been studied extensively $(7,14,16,17,50)$. Because kidney does not have a known stimulus-secretion coupling reaction in response to insulinotropic substances, we have compared islet ATPases with those of kidney. We thus have here described studies which investigate whether stimulus-secretion coupling could involve suppression of $\mathrm{Na}^{+} \mathrm{K}^{+}$ATPase, as well as alterations of other cationic pump ATPases.

Our data suggests that the ATPases have similar kinetic characteristics in both islets and kidney. Apparent $K_{m}$ (ATP) in islets and kidney for $\mathrm{Na}^{+} \mathrm{K}^{+}$and $\mathrm{Mg}^{++} \mathrm{ATPase}$ was in the ranges described for other tissues by Hokin (51). Similarly, our apparent $K_{m}$ (ATP) of $0.08 \mathrm{mM}$ for islet and kidney calcium ATPase was quite similar to that described by Formby et al. (52).

In our experiments, as in the work of others who used a variety of tissues $(12,53)$, larger amounts of potassium increased specific activity of $\mathrm{Na}^{+} \mathrm{K}^{+} A$.TPase. The tendency of $\mathrm{K}^{+}$to enhance dephosphorylation of the phosphoenzyme complex of this system (2) is a likely explanation for this observation.

Ouabain suppressed $\mathrm{Na}^{+} \mathrm{K}^{+}$ATPase in all experiments, whereas DPH enhanced this enzyme activity only at high $\mathrm{Na}$ : $\mathrm{K}$ ratios. This latter finding is similar to that of Festoff and Appel (22) in neural synaptosomes. Though there are several possible explanations, no experimental data has clarified the reasons for enhancement of $\mathrm{Na}^{+} \mathrm{K}^{+}$ATPase by DPH at high $\mathrm{Na}: \mathrm{K}$ ratios only. Nevertheless, we found that both inhibition and enhancement of the enzyme activity could be studied at the 250:1 (high) $\mathrm{Na}: \mathrm{K}$ ratio. Under these conditions, we found that ouabain and DPH influence $\mathrm{Na}^{+} \mathrm{K}^{+}-$ ATPase of both tissues; the first drug inhibits and the second enhances enzyme activity about $100 \%$. However, in response to insulinotropic substances, islet and renal tissue differed markedly.

Glucose $16.7 \mathrm{mM}$ was as potent as ouabain in suppressing islet $\mathrm{Na}^{+} \mathrm{K}^{+}$ATPase. In contrast, glucose had no effect on those renal ATPases which we meas- ured. The concentration of glucose which is stimulatory to insulin secretion $(16.7 \mathrm{mM})$ inhibited islet $\mathrm{Na}^{+} \mathrm{K}^{+}$ATPase to a greater degree than did the nonstimulatory concentration $(3.3 \mathrm{mM})$. Because threshold sensitivity to glucose is a well-described phenomenon (54), the ATPases could have a role in this sensitivity.

Glucose also inhibited islet $\mathrm{Ca}^{++}$ATPase at both high and low concentrations. This enzyme system is believed to pump $\mathrm{Ca}^{++}$against an electrical chemical gradient to the extracellular space (3). Because glucose induces a net uptake of islet calcium (55), the inhibition of this islet $\mathrm{Ca}^{++} \mathrm{ATPase}$ would facilitate the cytoplasmic accumulation of calcium associated with insulin secretion and production of adenosine $3^{\prime}, 5^{\prime}$ cyclic monophosphate (56).

In these experiments calcium inhibited $\mathrm{Na}^{+} \mathrm{K}^{+}$ ATPase. Formby et al. (52) showed that $\mathrm{Na}^{+}$inhibits islet calcium ATPase. Very high concentrations of $\mathrm{K}^{+}$, which inhibit $\mathrm{Na}^{+} \mathrm{K}^{+}$ATPase in a number of tissues (51), induce insulin secretion (57) and increase calcium uptake (58). Thus, interaction between the electrolytes and the enzymes that modulate them seems probable. $\mathrm{Na}^{+}$modulates $\mathrm{Ca}^{++}$influx across excitable membranes in some tissues (8) and, in gastrointestinal epithelium, $\mathrm{Na}^{+}$entry is required for glucose entry (59), which suggests $\mathrm{Na}^{+-} \mathrm{Ca}^{++}$reciprocity. Microtubules of certain mammalian cells contain calcium ATPase (60) and islet microtubular function seems to require calcium fluxes (39). Calcium shifts which could influence the microtubular-microfilamentous system $(61,62)$ could be, in part, regulated by the enzymes described. These enzymes could also modulate a number of other calcium compartments (63).

Arginine, which with a background substimulatory glucose level results in biphasic insulin release (41), suppressed islet $\mathrm{Na}^{+} \mathrm{K}^{+} \mathrm{ATPase}$. It had no effect on islet $\mathrm{Na}^{+} \mathrm{K}^{+}$ATPase when background glucose was omitted. In contrast, arginine suppressed $\mathrm{Na}^{+} \mathrm{K}^{+}-$ ATPase in kidney with or without background glucose. Thus, arginine may nonspecifically inhibit this enzyme in a number of cells. However, the presence of small amounts of glucose appear to be a requisite for arginine-induced inhibition of islet $\mathrm{Na}^{+} \mathrm{K}^{+} \mathrm{ATPase}$. High levels of arginine produce monophasic insulin release in vitro (41) in the absence of background glucose. Because some glucose is required for arginine-induced biphasic release, we suggest that ATPases may be related to this quality.

Leucine, which causes biphasic insulin secretion in the absence of glucose (64), inhibited islet $\mathrm{Ca}^{++}$. ATPase. Because leucine causes net uptake of calcium by islets (55), it could possibly trigger insulin release independent of enzyme coupled $\mathrm{Na}^{+}$fluxes.

Valine, which does not cause insulin secretion (43), did not alter ATPases in islets or kidney. This again points out that amino acid activation of islet function 
may be modulated through ATPases, and also suggests that the enzyme changes we noted were independent of changes in osmotic load.

In marked contrast to effects of secretagogues, the inhibitors of islet function, namely DPH, diazoxide, and ammonium chloride uniformly enhanced islet $\mathrm{Na}^{+} \mathrm{K}^{+}$ATPase. Characteristics of inhibition of insulin secretion by DPH and diazoxide have been extensively compared $(34,36)$. Differences in the inhibitory patterns have been emphasized and different mechanisms have been suggested with computer models (36). It is entirely possible, however, that the initial effects of these two drugs are the same, i.e., enhancement of $\mathrm{Na}^{+} \mathrm{K}^{+}$ATPase, thus leading to hyperpolarization of membranes.

Ammonium ion can substitute for $\mathrm{K}^{+}(1)$, and presumably can participate with potassium in the dephosphorylation of the phosphoenzyme (2), which is part of the ATPase reaction. This would explain increased $\mathrm{Na}^{+} \mathrm{K}^{+}$ATPase activity with $\mathrm{NH}_{4} \mathrm{Cl}$.

Inhibitors of insulin secretion had no effects on islet ATPases other than $\mathrm{Na}^{+} \mathrm{K}^{+}$ATPase. However, the effects of DPH and $\mathrm{NH}_{4} \mathrm{Cl}$ on $\mathrm{Na}^{+} \mathrm{K}^{+} \mathrm{ATPase}$ were similar in islets and kidney.

The membrane preparations used in our experiments very likely excluded many cytosolic enzyme systems (65). Thus, the influence of secretogenic substances and inhibitors upon islet ATPases could occur apart from effects upon cellular metabolism.

Lernmark et al. have recently shown that purified islet plasma membranes are rich in $\mathrm{Na}^{+} \mathrm{K}^{+} \mathrm{ATPase}(66)$. The presence of $\mathrm{Ca}^{++} \mathrm{ATPase}$ has been demonstrated in microtubules of certain cells (60) and in islet mitochondria, secretory granules, and microsomes (52). These findings suggest a role for these enzyme systems in the function of specialized cell structures (67-69).

The enzyme changes we observed in islets may represent largely those of beta cells, which comprise $75-80 \%$ of rat islets (70). Possible altered function of other islet cell types which influence total enzyme activity must be considered as well.

Despite the application of similar preparatory procedures to both islets and kidney, ATPase activity in the two tissues responded quite differently to substances which influence islet secretion. Because pellets from these tissues contained all of the cation-dependent ATPase activity which we measured, the data indicates that these enzymes are involved in specificity of islet response to substances which influence endocrine pancreatic function.

\section{ACKNOWLEDGMENTS}

The authors are grateful for the very skillful editorial assistance of Ms. Janet Tavarone.

This work was supported by a Veterans Administration grant 5218-01, and by grants from the American Diabetes
Association, Southern California Affiliate, Eli Lilly and Co., Indianapolis, Ind., and the Kroc Foundation.

\section{REFERENCES}

1. Skou, J. C. 1965. Enzymatic basis for active transport of $\mathrm{Na}$ and $\mathrm{K}$ across cell membrane. Physiol. Rev. 45: 596-617.

2. Robinson, J. D. 1974. Cation interactions with different functional states of the $\mathrm{Na}^{+} \mathrm{K}^{+}$ATPase. Ann. N. Y. Acad. Sci. 242: 185-202.

3. Schatzmann, H., and F. F. Vincenzi, 1969. Calcium movements across the membrane of human red cells.J. Physiol. (Lond.). 201: 369-395.

4. Hasselbach, W., M. Makinose, and W. Fiehn. 1970. Activation and inhibition of the sarcoplasmic calcium transport. In Calcium and Cellular Function. A. W. Cuthbert, editor. St. Martin's Press, New York. 75-84.

5. Askari, A., editor. 1974. Properties and Functions of $\left(\mathrm{Na}^{+} \mathrm{K}^{+}\right)$-Activated Adenosinetriphosphatase. Ann. N. Y. Acad. Sci. 242: 6-741.

6. Nakamaru, Y., M. Kosakai, and K. Konishi. 1967. Some properties of brain microsome ATPases activated by magnesium and calcium. Arch. Biochem. Biophys. 120: 1521.

7. Torretti, J. E., E. Hendler, E. Weinstein, R. Longnecker, and F. H. Epstein. 1972. Functional significance of $\mathrm{Na}^{+} \mathrm{K}^{+}$ATPase in the kidney: effects of ouabain inhibition. Am. J. Physiol. 222: 1398-1405.

8. Langer, G. A. 1971. The intrinsic control of myocardial contraction-ionic factors. N. Engl. J. Med. 285: 10651071.

9. Charney, A. N., M. D., Kinsey, L. Myers, R. A. Giannella, and $\mathrm{R}$. E. Gots. 1975. $\mathrm{Na}^{+}-\mathrm{K}^{+}$-activated adenosine triphosphatase and intestinal electrolyte transport-effect of adrenal steroids. J. Clin. Invest. 56: 653-660.

10. Ismail-Beigi, F., and I. S. Edelman. 1971. The mechanism of the calorigenic action of thyroid hormone. J. Gen. Physiol. 57: 710-722.

11. Katz, A. J., and F. H. Epstein. 1968. Physiologic role of $\mathrm{Na}^{+} \mathrm{K}^{+}$ATPase in the transport of cations across biologic membranes. N. Engl. J. Med. 278: 253-261.

12. Wheeler, K. P., and R. Whittam. 1962. Some properties of a kidney triphosphatase relevant to active cation transport. Biochem. J. 85: 495-507.

13. Lacy, P. E., and M. Kostianovsky. 1967. Method for the isolation of intact islets of Langerhans from the rat pancreas. Diabetes. 16: 35-39.

14. Hendler, E. D., J. Torretti, and F. H. Epstein. 1971. The distribution of sodium-potassium-activated adenosine triphosphatase in medulla and cortex of the kidney. $J$. Clin. Invest. 50: 1329-1337.

15. Parkinson, D. K., and I. C. Radde 1971. Properties of $\mathrm{Ca}^{++}$and $\mathrm{Mg}^{++}$activated ATP hydrolyzing enzyme in rat kidney cortex. Biochim. Biophys. Acta. 242: 238-246.

16. Jorgensen, P., and J. Skou. 1972. Purification and characterization of $\left(\mathrm{Na}^{+} \mathrm{K}^{+}\right)$ATPase $\mathrm{I}$. The influence of detergents on the activity of $\left(\mathrm{Na}^{+} \mathrm{K}^{+}\right)$ATPase in preparations from outer medulla of rabbit kidney. Biochim. Biophys. Acta. 233: 366-380.

17. Lane, L. K., J. H. Copenhaver, G. F. Lindenmayer, and A. Schwartz. 1973. Purification and characterization of an $\left.{ }^{3} \mathrm{H}\right)$ ouabain binding to the transport adenosine triphosphatase from outer medulla of canine kidney. J. Biol. Chem. 20: 7197-7200.

18. Fiske, C. H., and Y. Subbarow. 1925. The colorimetric determination of phosphorus. J. Biol. Chem. 66: 375-400.

19. Lowry, O. H., N. J. Rosebrough, A. L. Farr, and R. J 
Randall. 1951. Protein measurement with the Folin phenol reagent. J. Biol. Chem. 193: 265-275.

20. Siegel, G. J., and B. B. Goodwin. 1972. Sodium-potassium activated adenosine triphosphatase of brain microsomes: modification of sodium inhibition by diphenylhydantoins. J. Clin. Invest. 51: 1164-1169.

21. Post, R. L., and A. K. Sen. 1967. Sodium and potassium stimulated ATPase. Methods. Enzymol. 10: 762-768.

22. Festoff, B. W., and S. H. Appel. 1968. Effect of diphenylhydantoin on synaptosome sodium-potassium ATPase. J. Clin. Invest. 47: 2752-2758.

23. Hales, C. N., and R. D. Milner. 1968. The role of sodium and potassium in insulin secretion from rabbit pancreas. J. Physiol. (Lond.). 194: 725-743.

24. Triner, L., P. Killian, and G. Nahas. 1968. Ouabain hypoglycemia: insulin mediation. Science (Wash. D. C.). 162: $560-561$.

25. Chesney, T., and J. G. Schofield. 1969. Studies on the secretion of pancreatic glucagon. Diabetes. 18: 627-632.

26. Levin, S. R., and J. F. Driessen. 1975. Sodium-potassium ATPase in pancreatic islets: effects of ouabain, diphenylhydantoin and calcium. Diabetes. 24: 438. (Abstr.)

27. Levin, S. R., J. Driessen, M. Pehlevanian, R. Adachi, and B. Kasson. 1976. Do electrolyte pump enzymes have a role in islet cell function? Clin. Res. 24: 118. (Abstr.)

28. Peters, B. H., and N. A. Samaan. 1969. Hyperglycemia with relative hypoinsulinemia in diphenylhydantoin toxicity. N. Engl. J. Med. 281: 91.

29. Levin, S. R., J. Booker, D. F. Smith, and G. M. Grodsky. 1970. Inhibition of insulin secretion by diphenylhydantoin in the isolated, perfused pancreas. J. Clin. Endocrinol. Metab. 30: 400-401.

30. Kizer, J. S., M. Vargas-Cordon, K. Brendel, and R. Bressler. 1970. The in vitro inhibition of insulin secretion by diphenylhydantoin. J. Clin. Invest. 49: 1942-1948.

31. Farris, B., and C. L. Lutcher. 1971. Diphenylhydantoininduced hyperglycemia and impaired insulin release. Diabetes. 20: 177-181.

32. Malherbe, C., K. C. Burrill, S. R. Levin, J. H. Karam, and P. H. Forsham. 1972. Effect of diphenylhydantoin on insulin secretion in man. N. Engl.J. Med. 286: 330-342.

33. Gerich, J., M. A. Charles, S. R. Levin, P. H. Forsham, and G. M. Grodsky. 1972. In vitro inhibition of pancreatic glucagon secretion by diphenylhydantoin. J. Clin. Endocrinol. Metab. 35: 823-824.

34. Levin, S. R., G. M. Grodsky, R. Hagura, and D. Smith. 1972. Comparison of the inhibitory effects of diphenylhydantoin and diazoxide upon insulin secretion from the isolated, perfused pancreas. Diabetes. 21: 856-862.

35. Levin, S. R., J. W. Reed, K. N. Ching, J. W. Davis, M. R. Blum, and P. H. Forsham. 1973. Diphenylhydantoin: its use in detecting early insulin secretory defects in patients with mild glucose intolerance. Diabetes. 22: 194201.

36. Levin, S. R., M. A. Charles, M. O'Connor, and G. M. Grodsky. 1975. Use of diphenylhydantoin and diazoxide to investigate insulin secretory mechanisms. Am. J. Physiol. 229: 49-54.

37. Grodsky, G. M., and L. L. Bennett. 1966. Cation requirements for insulin secretion in the isolated, perfused pancreas. Diabetes. 15: 910-913.

38. Milner, R. D. G., and C. N. Hales. 1967. The role of calcium and magnesium in insulin secretion from rabbit pancreas studied in vitro. Diabetologia. 3: 47-49.

39. Malaisse, W. J., and F. Malaisse-Lagae. 1970. A possible role for calcium in the stimulus-secretion coupling for glucose-induced insulin secretion. Acta Diabetol. Lat. 7(Suppl. 1): 264-275.
40. Laclercq-Meyer, W., J. Marchaud, and W. J. Malaisse. 1973. The effect of calcium and magnesium on glucagon secretion. Endocrinology. 93: 1360-1370.

41. Levin, S. R., G. M. Grodsky, R. Hagura, D. F. Smith, and P. H. Forsham. 1972. Relationships between arginine and glucose in the induction of insulin secretion from the isolated, perfused rat pancreas. Endocrinology. 90: 1623.

42. Milner, R. D. G. 1970. The stimulation of insulin release by essential amino acids from rabbit pancreas in vitro. J. Endocrinol. 47: 347-356.

43. Malaisse, W. J., and F. Malaisse-Lagae. 1968. Stimulation of insulin secretion by noncarbohydrate metabolites. $J$. Lab. Clin. Med. 72: 438-448.

44. Feldman, J. M., and H. E. Lebovitz. 1971. Ammonium ion, a modulator of insulin secretion. Am. J. Physiol. 221: $1027-1032$.

45. Matthews, E. K. 1970. Calcium and hormone release. In Calcium and Cellular Function. A. W. Cuthbert, editor. St. Martin's Press, Inc., New York. 163-182.

46. Howell, S. L., and K. W. Taylor. 1968. Potassium ions and the secretion of insulin by islets of Langerhans incubated in vitro. Biochem. J. 198: 17-24.

47. Hales, C. N., and R. D. G. Milner. 1968. Cations and the secretion of insulin from rabbit pancreas in vitro. J. Physiol. (Lond.). 199: 177-187.

48. Sehlin, J., and I. Taljedal. 1974. Sodium uptake by microdissected pancreatic islets: effects of ouabain and chloromercuribenzene-p-sulphonic acid. F.E.B.S. (Fed. Eur. Biochem. Soc.) Lett. 39: 209-213.

49. Woodbury, D. M., 1955. Effect of diphenylhydantoin on electrolytes and radiosodium turnover in brain and other tissues of normal, hyponatremic, and postictal rats. $J$. Pharmacol. Exp. Ther. 115: 74-95.

50. Bastide, F., G. Meissner, S. Fleisher, and R. L. Pose. 1973. Similarity of the active site of phosphorylation of the adenosine triphosphatase for transport of sodium and potassium ions in kidney to that for transport of calcium ions in the sarcoplasmic reticulum of muscle. J. Biol. Chem. 248: 485-491.

51. Hokin, L. E. 1974. Purification and properties of the (sodium + potassium)-activated adenosine triphosphatase and reconstitution of sodium transport. Ann. N. Y. Acad. Sci. 242: 12-23.

52. Formby, K. J., Capito, J. Egeberg, and C. J. Hedeskov. 1976. Ca-activated ATPase activity in subcellular fractions of mouse pancreatic islets. Am. J. Physiol. 230: 441-448.

53. Baker, E., and W. J. Simmonds. 1966. Membrane ATPase and electrolyte levels in marsupial erythrocytes. Biochim. Biophys. Acta. 126: 492-499.

54. Grodsky, G. M. 1972. A threshold distribution hypothesis for packet storage of insulin and its mathematical modeling. J. Clin. Invest. 51: 2047-2059.

55. Levy, J., A. Herchuelz, A. Sener, and W. J. Malaisse. 1976. The stimulus secretion coupling of glucose-induced insulin release. XX. Fasting: A model for altered glucose recognition by the B-cell. Metab. Clin. Exp. 25: 583-591.

56. Charles, M. A., J. Lawecki, R. Pictet and G. M. Grodsky. 1975. Insulin secretion: interrelationships of glucose, cyclic adenosine $3^{\prime}: 5^{\prime}$ monophosphate, and calcium. $J$. Biol. Chem. 250: 6134-6146.

57. Henquin, J. C., and A. E. Lambert. 1974. Cationic environment and dynamics of insulin secretion. II. Effect of a high concentration of potassium. Diabetes. 23: 933-942.

58. Malaisse-Lagae, F., and W. J. Malaisse. 1971. Stimulussecretion coupling of glucose-induced insulin release. III. 
Uptake of ${ }^{45}$ calcium by isolated islets of Langerhans. Endocrinology. 88: 72-80.

59. Gray, G. M. 1975. Carbohydrate digestion and absorption. N. Engl. J. Med. 292: 1225-1230.

60. Nagayama, A., and S. Dales. 1970. Rapid purification and the immunological specificity of mamallian microtubular crystals possessing and ATPase activity. Proc. Natl. Acad. Sci. U. S. A. 66: 464-471.

61. Lacy, P. E., M. M. Walker, and J. Fink. 1972. Perifusion of isolated rat islets in vitro. Participation of the microtubular system in the biphasic release of insulin. Diabetes. 21: $987-988$.

62. Malaisse, W. J. 1973. Insulin secretion: multifactorial regulation for a single process of release. Diabetologia. 9: $167-173$.

63. Hellman, B., J. Sehlin, I. B. Taljedal. 1976. Calcium and secretion: distinction between two pools of glucose-sensitive calcium in pancreatic islets. Science (Wash. D. C.). 194: $1421-1423$.

64. Basabe, J. C., N. L. Lopez, J. K. Viktora, and F. W. Wolff. 1971. Insulin secretion studied in the perfused rat pancreas I. Effect of tolbutamide, leucine and arginine; their interaction with diazoxide, and relation to glucose. Diabetes. 20: 449-456.

65. DeDuve, C., R. Wattiaux and P. Baudhuin. 1962. Distribution of enzymes between subcellular fractions in animal tissues. Adv. Enzymol. Relat. Areas Mol. Biol. 24: $291-358$.

66. Lernmark, A., A. Nathans, and D. F. Steiner, 1976. Preparation and characterization of plasma membrane-enriched fractions from pancreatic islets. J. Cell Biol. 71: 606-623.

67. Formby, B., K. Capito, and C. J. Hedeskov. 1976. $\left(\mathrm{Na}^{+} \mathrm{K}^{+}\right)$ activated ATPase in microsomes from mouse pancreatic islets. Acta Physiol. Scand. 96: 143-144.

68. Niki, A., H. Niki, I. Miwa, and J. Okuda. 1974. Insulin secretion by anomers of D-glucose. Science (Wash. D. C.). 186: $150-151$.

69. Grodsky, G. M., F. Fanska, L. West, and M. Manning. 1974. Anomeric specificity of glucose-stimulated insulin release: evidence for a glucoreceptor? Science (Wash. D. C.). 186: 536-538.

70. Pictet, R., and W. J. Rutter. 1972. Development of the embryonic endocrine pancreas. Handb. Physiol. 1(Sect. 7, Endocrinology): 50. 